\title{
GAZE TO SEASHORE: COMPARATIVE ANALYSIS BETWEEN EUROPE AND JAPAN
}

\author{
H. KATO \\ Center for Advanced Tourism Studies, Hokkaido University, Japan.
}

\begin{abstract}
Media including paintings, wooden prints, pictures, drawings, and postcards were analysed to clarify what kinds of activities for recreation and pleasure took place on the shore in Japan since the premodern age, and compared with the counterparts in the European society to find the magnitude and extent of their influence. Major information sources of this study are more than 30 digital archive services provided by museums and libraries both in Japan and in the western society. Publications also played major roles to identify how the shoreline and sea were felt and exploited by the general public in both regions. Coastal cities and port towns in both regions were visited by the author. The study revealed that clear division exists between the two societies since the pre-modern age as to the gaze toward the shores; in Japan the shores have been regarded as holy places and utilized for recreation and pleasure activities as well while in Europe the shores have been regarded as unstable, uncivilised and filthy places, and people believed that monsters lived in the sea. The study also clearly identified that even before the advent of the modern society Japanese people enjoyed an open atmosphere along beach streets which lay within a short distance from the city centre. People enjoyed on the beach street to watch a rising moon and a migration of birds. These results demonstrate that the influence of the European seaside culture on the Japanese counterpart in the early modern stage was limited as far as an aesthetic sense toward the shore was concerned. The study indicates that Japanese people have their own visual sense with unique historical background, and pursue ways for the sustainability of their way of life based on their own.

Keywords: beach, image, one-sided, open, pier, port, promenade, seaside resort, Takanawa, view.
\end{abstract}

\section{INTRODUCTION}

\subsection{Background}

More than 60 percent of the top 100 Japanese cities in terms of population size lie on the coast, and about one quarter of the coastline is under port jurisdiction. Thus, seashore has been an important resource in both economic and recreational activities in Japan. High priority is given in the policies for both the central and local governments to provide citizens and visitors with easy access to the seashore and to make the waterfronts enjoyable and comfortable.

Understanding of what kind of image and aesthetic sense Japanese people inherit on the sea is required to make the waterfronts in Japan enjoyable and comfortable. Unlike the European seaside culture, only limited number of articles has dealt with Japanese seaside culture in the Pre-modern age.

Technology and culture of Europe rushed into Japan after the later stage of Tokugawa period (1606-1868). It is important to make it clear whether 'scenery' existed or not before the Westerners came into the foreign settlements and taught the Japanese people [1].

This paper is part of the Proceedings of the $7^{\text {th }}$ International Conference on Sustainable Tourism (Sustainable Tourism 2016)

www.witconferences.com
} 
1.2 Objectives of the study

1. To clarify the Japanese people's inheritance on the sea in the pre-modern age

2. To compare the ways of feeling of the European and the Japanese on the sea

3. To clarify the magnitude of European influence on the Japanese sea culture

\subsection{Methodology}

Field visits to seashores and ports both in Europe and Japan were made during 2013 through 2015. Media including paintings, wooden prints, pictures, drawings and postcards that are closely related to the study purposes were analysed. Digital archive services of museums and libraries were utilized (Table 1).

\subsection{Definition in this paper}

1. Pre-modern age

In Europe, from the mid-15th century to the French Revolution.

In Japan, from the mid-16th century to the mid-19th century.

2. Modern age

In Europe, after the French revolution. In Japan, after concluding trade treaties with Western nations.

\section{IMAGES AND ACTIVITIES ON THE SEA IN EUROPE}

\subsection{Pre-modern age in Europe}

\subsubsection{Images on the sea}

Myths had a strong influence on the people's image on the sea during the Pre-modern age in Europe. People conceived of the sea as uncivilised and vulgar, and a world where gods had not touched yet and monsters lived. People also regarded the seashore as a border between our world and the underworld where no order/discipline existed, hence being unstable.

Alain Corbin [2] writes Europeans' images on the sea as follows;

The ocean, that watery monsters' den, was a damned world in whose darkness the accursed creatures devoured one another (p. 7).

On the sea-shore monsters lurk: Scylla surrounded by her barking dogs and the sly Charybdis who gulps down and vomits her victims (p. 13).

The shore in antiquity was also the receptacle of the sea's rejections; it is along the beach that the ocean purges itself and throws up its monsters (p. 13).

Christopher Marsden [3] explains that the sea was not the subject to admire for European people in the Pre-modern age;

Until the mid-eighteenth century, the sea was to our forefathers a phenomenon to be feared, accepted and, as occasion demanded, to be employed. It was to them a highway, a fishpond, a battle-ground - and a graveyard. To them it had no beauty, no soft attractions (p. 9). 
Table 1: List of museums and libraries service received in this study

\begin{tabular}{|c|c|}
\hline Museum & Archive \\
\hline Tokyo National Museum & Old photos database (about 3,700materials) \& old mapa database \\
\hline National Diet Library & $\begin{array}{l}\text { the landmarks of Edo in color woodblock prints ( } 103 \text { places, } 484 \text { pieces) } \\
\text { and the Meiji and Iaisho eras in photographs (about } 500 \text { pieces) }\end{array}$ \\
\hline $\begin{array}{l}\text { National Archives of } \\
\text { Japan }\end{array}$ & $\begin{array}{l}\text { provides on-line catalog database, some including } \\
\text { digital images.including } 2015 \text { rare materials. }\end{array}$ \\
\hline $\begin{array}{l}\text { The Metropolitan } \\
\text { Museum of Ait }\end{array}$ & $\begin{array}{l}\text { This museum holds more than } 4 \text { million materials and more than 400,000 } \\
\text { works of arts can be explored by Collection Online. }\end{array}$ \\
\hline The British Museum & $\begin{array}{l}\text { Collection online - Approximately } 8 \text { million materials including artworks } \\
\text { and books of all ages and countries are stored up. }\end{array}$ \\
\hline $\begin{array}{l}\text { Bibliothèque nationale de } \\
\text { France }\end{array}$ & $\begin{array}{l}\text { the BnF's digital library, Gallica } \text {, provides access to over three millions } \\
\text { documents including more than } 70,000 \text { maps. }\end{array}$ \\
\hline $\begin{array}{l}\text { Flokkaidou University } \\
\text { Library }\end{array}$ & $\begin{array}{l}\text { Northem studies collection including Eokkaido related photos \& maps } \\
5,000 \text { each. }\end{array}$ \\
\hline $\begin{array}{l}\text { The National Institute of } \\
\text { Japanese Literature }\end{array}$ & $\begin{array}{l}\text { NJIL holds } 33 \text { categorised databases including } \\
\text { Japanese industrial history collection ( } 13,643 \text { images). }\end{array}$ \\
\hline $\begin{array}{l}\text { The Open University of } \\
\text { Japan Library }\end{array}$ & $\begin{array}{l}\text { approximately } 200 \text { points of Old photo graphs for the Meiji period through } \\
\text { the late Tokugawa period }\end{array}$ \\
\hline $\begin{array}{l}\text { Nagasaki University } \\
\text { Library }^{7}\end{array}$ & $\begin{array}{l}\text { approximately } 7000 \text { old photographs, taken all over Japan from the } \\
\text { Bakumatsu through to the Meiji period. }\end{array}$ \\
\hline $\begin{array}{l}\text { Waseda University } \\
\text { Libraty }\end{array}$ & $\begin{array}{l}\text { The collection of some } 300,000 \text { items of the Japanese and Chinese classics } \\
\text { with detailed bibliographical infonnation and clear full-color images. }\end{array}$ \\
\hline Postcard Museum & $\begin{array}{l}\text { Over } 10,000 \text { of Japanese and foreign post cards. } \\
\text { Large-sized photos. Sugoroku posters, etc. }\end{array}$ \\
\hline $\begin{array}{l}\text { Hakodate City Central } \\
\text { Library }\end{array}$ & $\begin{array}{l}\text { Degital library holds ultrafine degital image database } \\
\text { containing old maps photos and picture postcards. }\end{array}$ \\
\hline $\begin{array}{l}\text { Niigata Furumachi } \\
\text { Rekishikann }\end{array}$ & Birth of Furumachi- old pictures and drawings talk about \\
\hline \multicolumn{2}{|c|}{$\begin{array}{l}\text { MXArOPLA-Xiigata City Niigata photo books (can be searched by places and topics) } \\
\text { History Museum }\end{array}$} \\
\hline $\begin{array}{l}\text { Kanagawa Prefectural } \\
\text { Museum of Cultural } \\
\text { History }\end{array}$ & $\begin{array}{l}\text { Degital Museum provides arts and documents including wood block prints } \\
\text { and old maps related to Kanagawa prefecture. }\end{array}$ \\
\hline $\begin{array}{l}\text { Yokohama archives of } \\
\text { history }\end{array}$ & $\begin{array}{l}\text { over } 250,000 \text { materials including Nishikie, photos, and picture postcards } \\
\text { around port opening period. }\end{array}$ \\
\hline $\begin{array}{l}\text { Yokohama Flistoiy } \\
\text { Museum }\end{array}$ & $\begin{array}{l}\text { Under the theme of "Daily life and social history in Yokohama" the } \\
\text { museum exhibits historial items of the city area over } 20,000 \text { years. }\end{array}$ \\
\hline $\begin{array}{l}\text { Museum of Yokohama } \\
\text { Urban Flistoiy }^{7}\end{array}$ & $\begin{array}{l}\text { Yokohaina History Information Map -history information system that a } \\
\text { document database coupled with Yokohama history information map }\end{array}$ \\
\hline Shiga University Library & $\begin{array}{l}\text { Approximately } 160,000 \text { items in total are stored including } 1,000 \text { materials } \\
\text { of common people documents of the early modern times. }\end{array}$ \\
\hline $\begin{array}{l}\text { Osaka Museum of } \\
\text { History }\end{array}$ & $\begin{array}{l}\text { The museum holds about } 100,000 \text { materials including old Osaka } \\
\text { photographs. }\end{array}$ \\
\hline
\end{tabular}


Table 1: (Continued)

\begin{tabular}{|c|c|}
\hline Museum & Archive \\
\hline Sakai Municipal Library & $\begin{array}{l}\text { Collection includes } 320 \text { postcards, digital documents and Sakai photo- } \\
\text { graphs ( } 75 \text { images) }\end{array}$ \\
\hline $\begin{array}{l}\text { Flyogo Prefectural } \\
\text { Museum of Flistoiy }\end{array}$ & Hlyogo History Road: Journey to the Edo Period (57 images) \\
\hline Kobe City Museum. & $\begin{array}{l}\text { approximately } 240 \text { most important documents among } 70,000 \text { items overall } \\
\text { stocked in the museum are degitized and displayed }\end{array}$ \\
\hline $\begin{array}{l}\text { Kobe City Municipal } \\
\text { Library }\end{array}$ & Degital archives of 65 images for rare materids \\
\hline Kobe University Library & $\begin{array}{l}\text { Digitization shows a part of the maritime document collection "Sumita } \\
\text { library" of the Edo period and early Meiji period. }\end{array}$ \\
\hline $\begin{array}{l}\text { Nagasaki Museum of } \\
\text { History and Culture }\end{array}$ & $\begin{array}{l}\text { The museum holds about } 48,000 \text { pieces of historical documents of foreign } \\
\text { exchange. Some of them can be accessed by web. }\end{array}$ \\
\hline $\begin{array}{l}\text { Fukuoka Prefectural } \\
\text { Library }\end{array}$ & $\begin{array}{l}\text { The museum collection includes Philipp Franz Balthasar von Siebold's } \\
\text { collection [NIPPON] . }\end{array}$ \\
\hline Transportation Museum & $\begin{array}{l}\text { Closed on } 6 \text { April 2014. Some of the documents and woodstock prints can } \\
\text { be accessed on web. }\end{array}$ \\
\hline Museum of Logistics & $\begin{array}{l}\text { Tlie museum collection includes } 6000 \text { documents, over } 100,000 \text { photos, } \\
\text { and about } 200 \text { movies. Railway nishild-e can be accessed on web. }\end{array}$ \\
\hline Minato Citv Library & $\begin{array}{l}\text { "Prominent people of Minato city" contains ukiyo-e (woodblockprints) on } \\
\text { popular places and people's activities in Edo - Meiji periods. }\end{array}$ \\
\hline
\end{tabular}

Between 1690 and 1730, natural theology unfolded across the Western world. The rise of the natural theology supported the standpoint to regard human rationalism and sensitivity as important. Further, it opened a way to review the aesthetic value of the sea and shore, leading a way to medical water-taking. At the end of the 18th century, the word 'seaside' first used with its modern - healthful or pleasurable - implication (p. 12) [3].

\subsubsection{Activities on the sea}

C. J. Vernet (1714-1789)'s pictures were analysed to find how Europeans played and performed on the seashore. There are several pictures which portrayed a few people enjoying fishing or picking shellfish on the seashore, but few pictures have compositions of a large number of people enjoying on the beach. This indicates that enjoying on the beach was not a popular leisure activity among people in the pre-modern age in Europe.

\subsubsection{City walls blocking visibility}

Fukazawa [4] suggests that there were two (2) types of port cities when classified according to existence or nonexistence of city walls at the port-city border: closed type and open type. Nant belongs to the former, and Marseille is categorised into the latter.

Kato [5] analysed and classified many port cities in Europe based on old drawings and maps. His interest was whether visibility and accessibility to the port from city centre was secured or not. He concluded that it is reasonable to consider that in many port cities visibility was restricted by the city walls and people in general did not have free access to the port area. 


\subsection{Modern age in Europe}

\subsubsection{Conversion of norms of beauty}

Conversion of the norm of beauty happened in the Western society from the late 18th century through the early 19th century. A concept called 'picturesque' evolved in UK during this period. This term was used to describe scenery or remains which emerged complicated feelings such as being surprised, impressed, or unexpected. An aesthetic sense called 'sublimity' was also generated in Europe. A peculiar natural phenomenon was taken as divine in this aesthetic sense.

\subsubsection{Activities on the sea}

2.2.2.1 Stroll along the shore It is observed that during this period of time, many painters in Europe took the scenery of walking on the seaside promenade as a subject of a painting. Unlike an inland promenade, a seaside promenade is a one-sided walking pass, and opens to the sea. This behaviour shows that people liked to look out over the sea.

2.2.2.2 Seaside resort The city wall which had been separating the sea from towns had been removed. This caused a big change to the people's gaze to the sea. Workers left their factories and went to the sea. What they saw was a very large sandy beach, called a foreshore, which appeared after the tide went down.

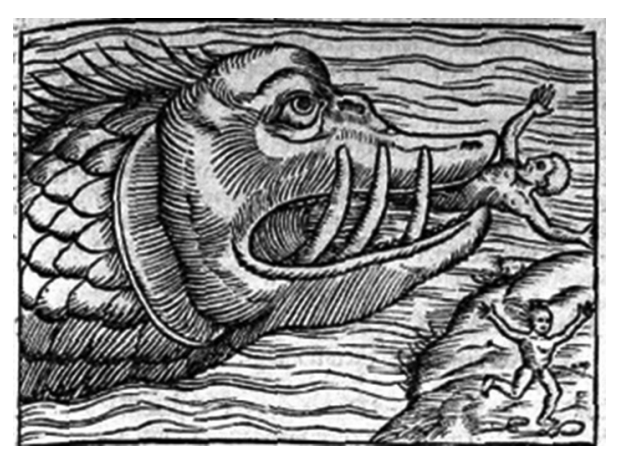

Figure 1: Sea monster, Petrus,H.,1552, Paris National Library.

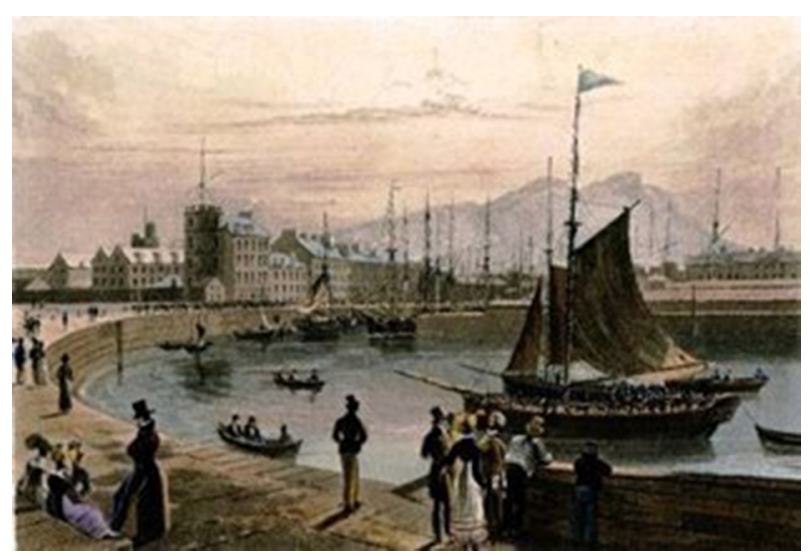

Figure 2: Leith, William, D., 1822, British Museum. 


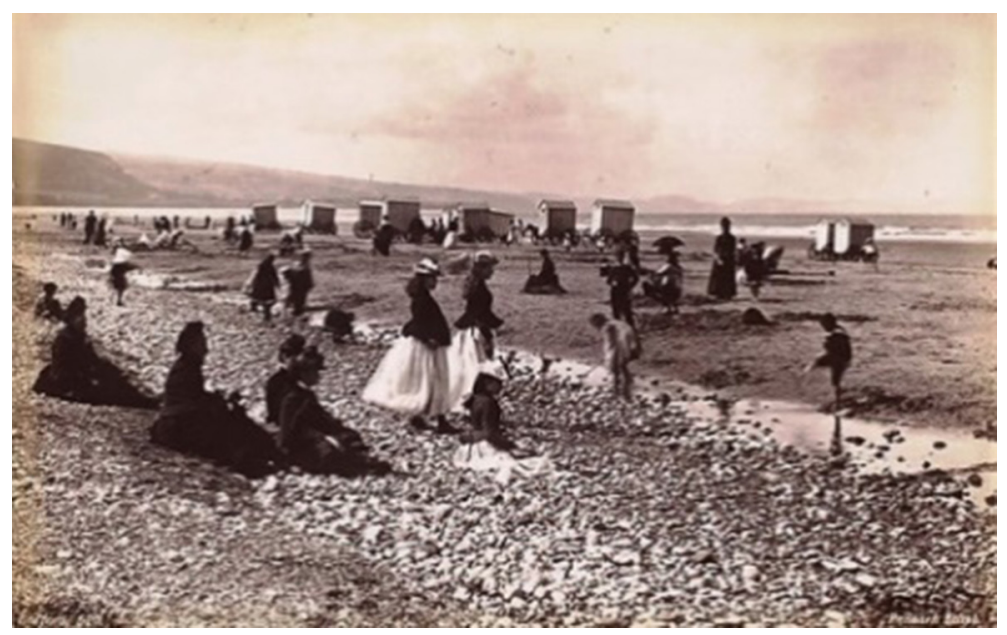

Figure 3: Pensarn beach, Bedford, F., 1860s, Metropolitan Museum.

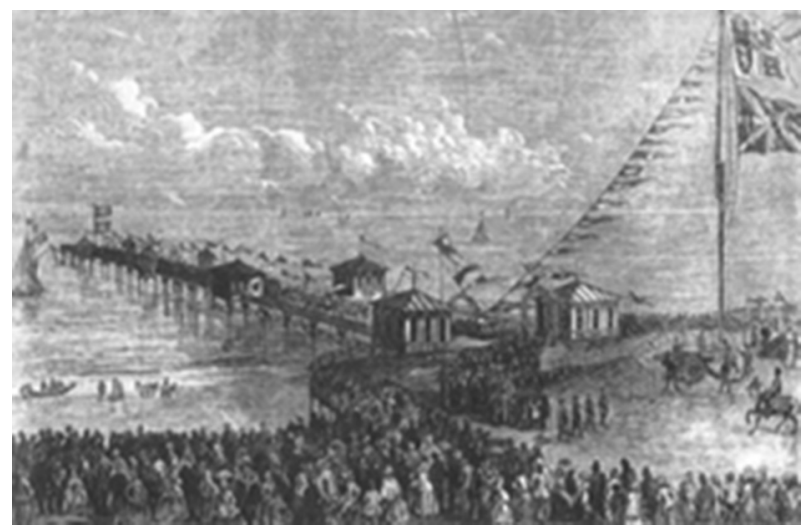

Figure 4: Blackpool North Pier, 1863, Blackpool District Library, ([6], p. 23).

2.2.2.3 Pleasure pier A set of beach, promenade and pleasure pier was developed at many British seaside resorts during the end of the 18th century through the early 19th century. A long pier was able to accommodate ships at even low tides, and while walking on the piers people enjoyed new perspectives of landscape and sea breezing, which was said to be good for health.

\section{IMAGES AND ACTIVITIES ON THE SEA IN JAPAN}

3.1 Pre-modern age in Japan

\subsubsection{Images on the sea}

Unlike western people, Japanese people in the Pre-modern age generally did not regard the sea as dangerous and dirty place, but rather regarded it as a holy place. This general tendency 
of the Japanese people's image about the sea can be found in several myths, fairy tales, and folk stories as well as prints and books.

3.1.1.1 Nirai Kanai Nirai Kanai is the mythical paradise from which all lives originate. This myth is believed particularly in Amami and Okinawa regions in the southern part of the Japanese archipelago. This holy world is believed to exist in the bottom of the sea of the far far-off east. Gods from Nirai Kanai are said to come over villages where people live at the beginning of the year and bring an abundant harvest, and return again at the end of the year. 3.1.1.2 Special privilege and promised happiness Yanagida pointed out that people in the long stretch of the south western archipelagos and a part of native Taiwanese even now believe the existence of the gods' world which lies facing to the east, sun rising direction. He stresses a fortune of a person who goes into the gods' country at the bottom of the sea, saying that it is a special privilege to visit there, and bringing happiness was seemingly a promise from the beginning of this narration ([7], pp. 24-25).

3.1.1.3 Seaside where gods land According to Chii, places where gods enter the land of living are usually natural shoreline such as a sandy beach, rock beach or reef at the seaside ([8], p. 57). People believe that the shoreline is a border domain with the world of gods and that of human beings, and a beach of this village is the place where villagers meet the gods ([8], p. 59).

3.1.1.4 Purification with sea water to receive gods Sea water or salt is widely believed among Japanese people to have power to purify things. Religious customs using sea water are practicing among people in Izumo area of Japan. On the early morning of the 1st day of each month, people go to the beach and obtain seawater with a pipe made of bamboo. Then they go and worship at the Izumo Taisha Shrine and sprinkle seawater with bamboo leaves to purify themselves. They subsequently sprinkle it on home entrances, household altar shrines, and each room [9]. Woodblock prints produced in the early 19th century by Kitagawa Utamaro clearly show this religious practice.

3.1.1.5 Life under the sea Narration of the web-exhibition on life under the sea held at Paris National Library explains Japanese people's images on the sea as follows; 'as early as the 17th century, Japanese manuscripts portrayed, in palaces located at the bottom of the sea, a way of life both sweet and gentle', and 'Numerous tales of extremely various cultures describe travels and exchanges made by men under the sea or by marine creatures on land' [10].

\subsubsection{Activities on the sea}

3.1.2.1 Viewing Even in the pre-modern era, Japanese people enjoyed viewing the natural seashore and admired its beauty. In particular, a sandy beach was loved by people and described as one of the popular tourist spots. Figure 5 shows a typical seashore scene on Maiko Beach near Kobe. On a guide book a man in the tea house is illustrated as enjoying scenery of the opposite shore at Awaji Island over the sea. On the beach, two men are enjoying a tea ceremony. It was one of the entertainments of the Edo era for tourists to look at Awaji Island over the Seto Inland Sea from this beach.

3.1.2.2 Shellfish gathering A shellfish gathering seemed to be one of the most popular recreational activities among common people. This activity was illustrated many times in ukiyo-e prints, and around the end of the 18th century Utamaro Kitagawa produced a work named 'Shiohi-no-tsuto', which means a souvenir of the shellfish gathering in Japanese. 

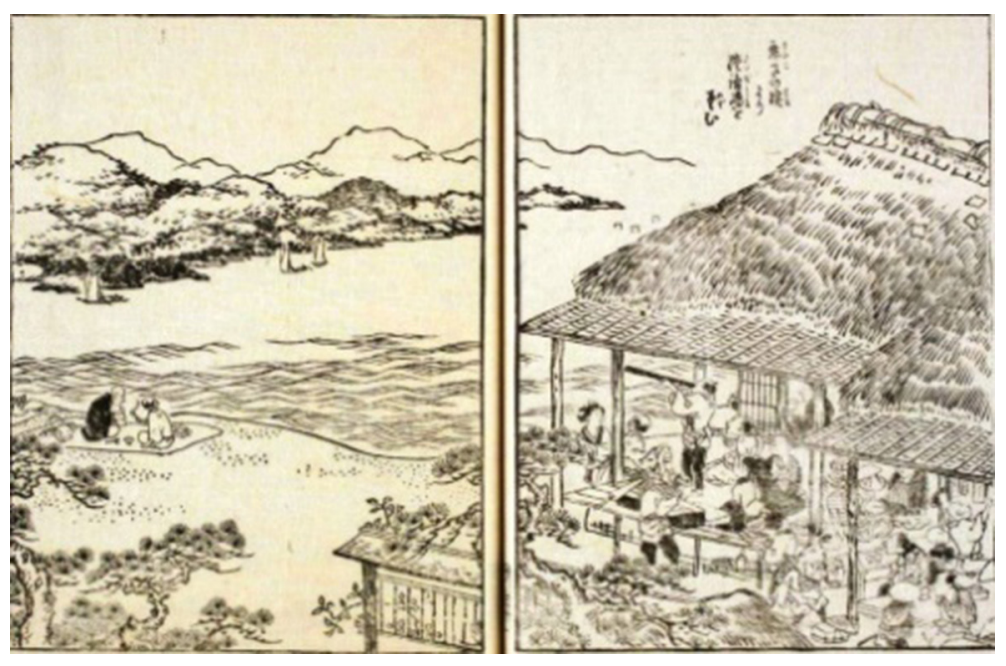

Figure 5: Viewing Awaji Is. from Maiko beach, Hyogo Pref. Museum of History.

3.1.2.3 Swimming Utamaro Kitagawa left one piece of coloured woodblock print. In this print, children are swimming happily around a boat on the sea while women are watching them aboard. It is said that this print was produced in the late 18th century when foreign trade was severely restricted only to Dejima, Nagasaki. European influence with respect to the representation on the sea cannot be found in this picture.

3.1.2.4 Takanawa - Walking along the one-sided street Takanawa Okido, which means a large gate in Takanawa in Japanese, was built at the Takanawa coast in 1710. Takanawa lies at the southern corner of the capital. Unlike a kido (gate) which guards each town, the main function of the Okido was to guard the whole of the capital. Edo (former name of Tokyo) was the capital of Japan during the Edo era from 1603 to 1868 with a population in the neighbourhood of 1,500,000-2,000,000 people.

The Takanawa Okido also played a role as a border between city and suburbs. Areas outside of the Takanawa Okido were the suburbs of Edo, not the city. Therefore, travels at that time started from the Takanawa Okido. Many people came to the Takanawa coast to see-off travellers.

A broad view unfolds suddenly on the left side of the coastal road when people come from the castle or downtown. Tokaido, which served as a national trunk road to connect Edo with Kyoto where Emperor resided, passed through the Takanawa district. A solid stone revetment was built through Shinagawa along the coast.

As Edo was a large consumption city, huge amount of consumption goods including rice was supplied by ships from every corner of the nation. From the Takanawa coast several big boats anchoring offshore were clearly visible. In addition, medium-sized ships with white sails and lighters were busy for loading/unloading and carrying cargos.

The Takanawa coast was hustle-bustle even in the evening. In special occasions such as full moon, people enjoyed a moon viewing party as well as a bird-migration viewing party on the Takanawa coast. There were many resting booths and restaurants along the seashore to enjoy the seaside atmosphere.

Takanawa beach had curved topography and was loved by tourists as well as residents, and was celebrated in poems and sketched in pictures/prints repeatedly. Not only Hiroshige, but 


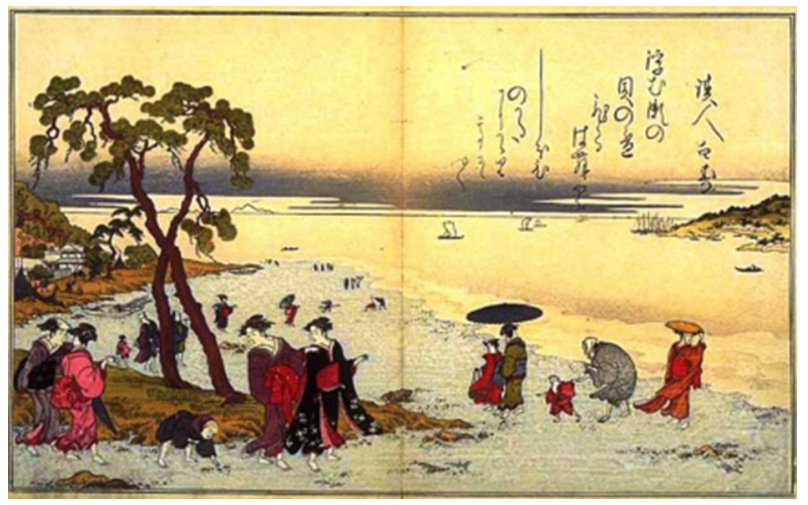

Figure 6: Shiohi-no-Tsuto, 1789, National institute of Japanese literature.

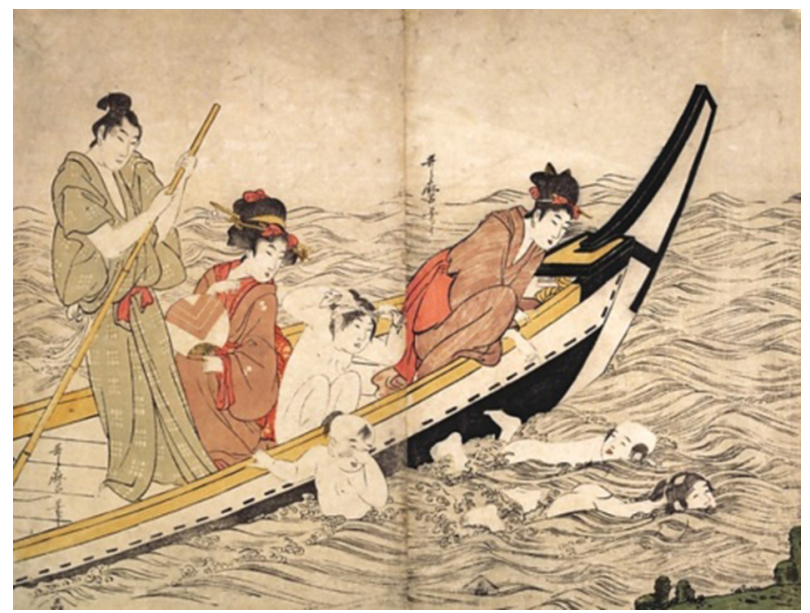

Figure 7: Boating party with children swimming, 18c, Metropolitan museum.

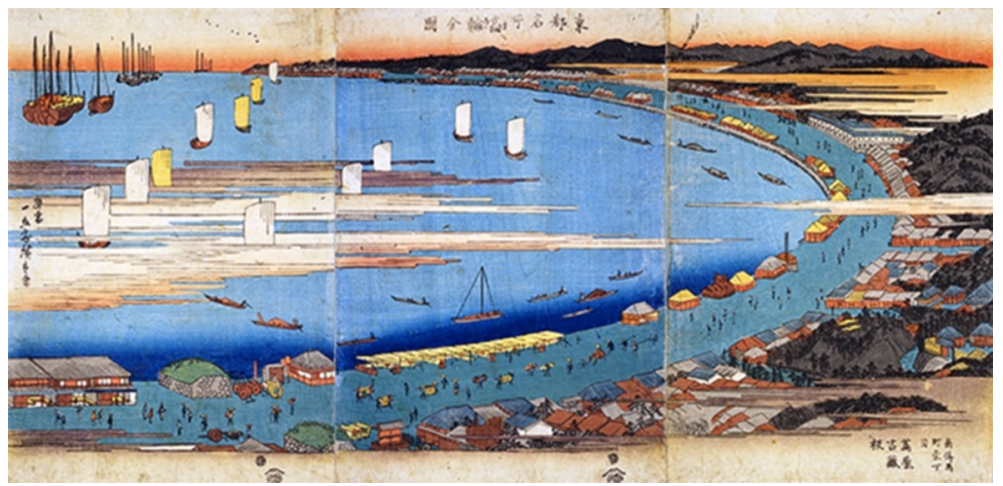

Figure 8: Takanawa Zenzu, Toto Meisho, Hiroshige I, Circa 1832-1842, National Diet Library. 


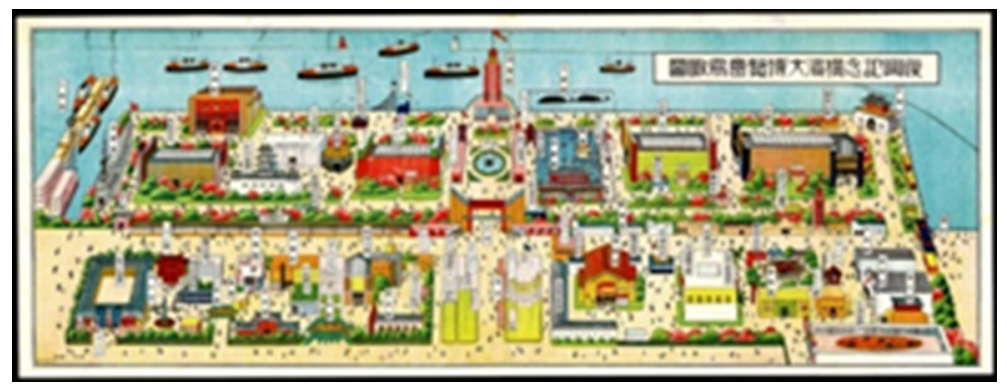

Figure 9: Bird-eye view of the grand Yokohama exhibition, 1935, Yokohama archive of history.

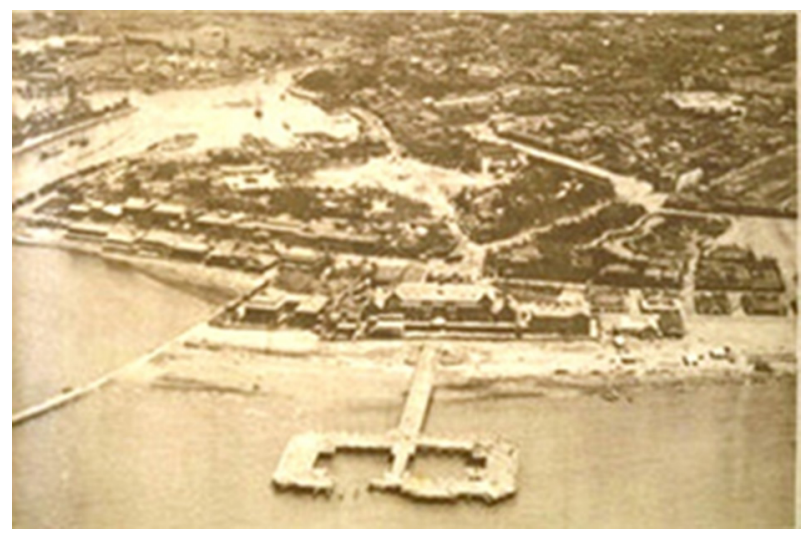

Figure 10: Aerial view of Ohama Kairo, early Showa era, Asahi Shinbun.

also other famous illustrators including Hokusai Katsushika and Toyokuni created works portraying the coastal view of the Takanawa beach. There existed a seaside opening space and magnificent coastal view in Edo.

\subsection{Modern age in Japan}

\subsubsection{Seaside bund}

After Yokohama Port was opened in 1859 for foreign trade, three (3) treaties were concluded for the construction of the Yokohama foreign settlement. Particularly important was the 1860 treaty which contained agreements to extend the existed bund of the foreign settlement. Provision of a bund along their seashore was observed in other colonial cities such as Shanghai. This practice parallels the popularity in Victorian seaside resorts [11].

This seaside bund, however, did not last long. A big earthquake (Great Kanto earthquake of 1923) hit the metropolitan area including Yokohama, and most of the buildings were destroyed. The government decided to reclaim the sea area along the foreign settlement for the creation of dumping site. After having been filled up, the area was converted to a park, now called Yamashita Park. 


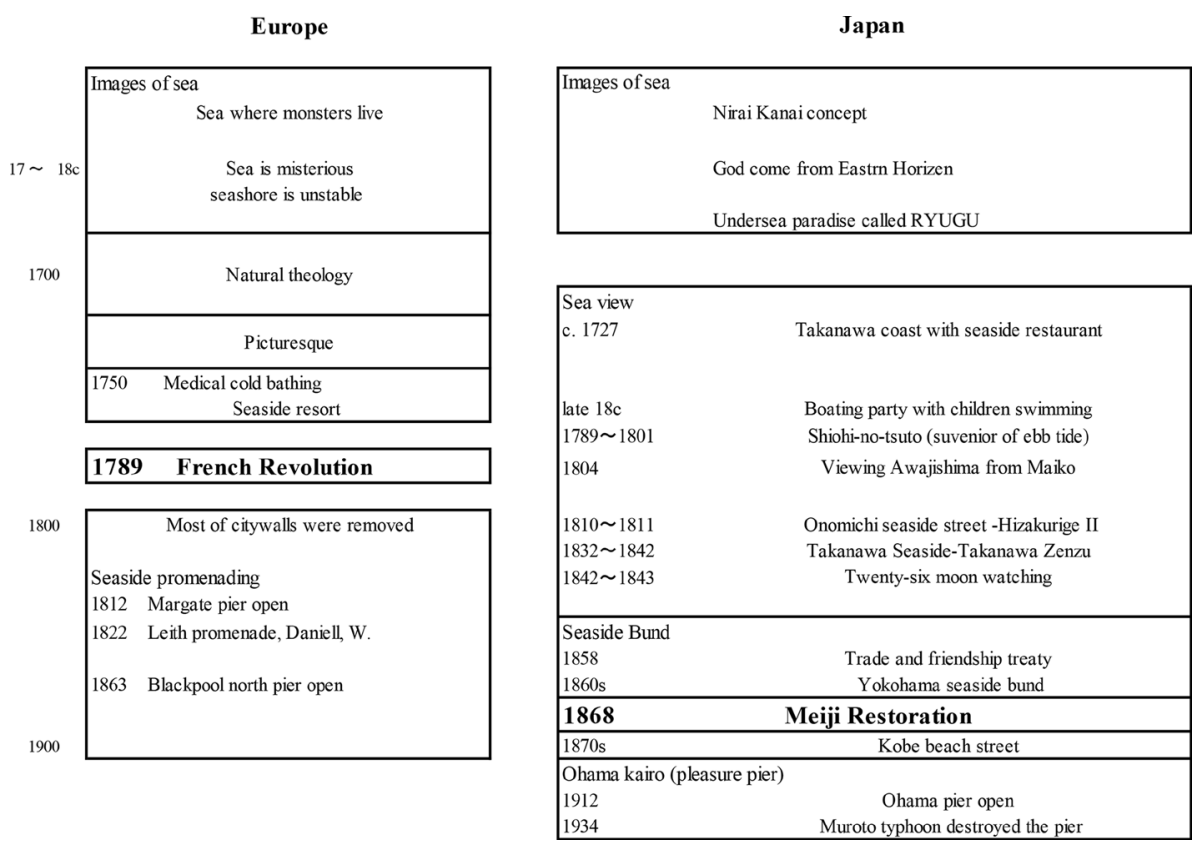

Figure 11: Chronological events.

\subsubsection{Pleasure pier}

From the end of Meiji era through Taisho era, leisure at the beach became popular in Japan. In this process, the pleasure pier concept developed in the UK was introduced to Japan. A pleasure pier called Ohama Kairo (sea pavilion in Japanese) was built at Ohama, Sakai. This pier was originally built for unloading coal, then enlarged and converted to a pleasure pier in 1912 (pp. 84-88) [12].

A typical style of the Japanese beach resort was observed at Ohama. Many restaurant inns were lined up along the beach. A pavilion called Shioyu where sea water was taken into and warmed up for bathing was built adjacent to the beach, and directly connected with the Ohama kairo. The pier and the bathing pavilion were decorated with many illuminations. Fireworks and open-air film festivals were held on the pier as well as moon viewing parties. The Ohama kairo was advertised as a simulated Nirai Kanai where gods live and play.

Facilities and devices such as a seaside bund and a pleasure pier were introduced into Japan, but they actually did not deeply root into the Japanese culture. Seaside of the Yokohama bund was reclaimed for a dumping area and afterwards converted to a public park. After the Muroto typhoon destroyed almost all of the coastal facilities, the Ohama kairo was abandoned, and no other pleasure piers were built elsewhere in Japan. It can be said that the imported Western seaside culture gradually changed its appearance and got watered down.

\section{RESULTS AND DISCUSSIONS}

(1) Unique image on the sea for Japanese people

In the pre-modern age of Europe, the sea was regarded as 'incomplete domain' where a hand of God had not yet touched upon and was considered to be a rough place, an uncivilised land, and where monsters lived. Seashore was recognized as an unstable place, too. Then 
natural theology, which rose in Europe from 1690 through 1730, supported the standpoint to regard human rationalism and sensitivity as important. Further, it opened a way to review the aesthetic value of the sea and shore, leading a way to medical bathing in the cold seawater.

Contrary to the Western society, a psychological gap or boundary between the sea and the land where people lived could not be found in old drawings or woodblock prints produced in the pre-modern age in Japan. It can be pointed out that Japanese people of the pre-modern age united the sea and the beach in a single entity.

From this observation, it can be said that image on the sea which Japanese people had was not introduced by the European people, but originated from the Japanese inherent sensitivity and aestheticism of their own.

(2) Forerunner of the seaside open space

Seaside open space already existed in the Tokugawa era (1603-1868) before Western people came to Japan for commerce and trade. Takanawa coast, a sea viewing and a curved street at the outskirt of the capital Edo can be a typical example. Takanawa coast street was constructed at almost the same time or even before seaside promenades were built and loved in Europe.

Takanawa coast was loved and highly popular among travellers passing by. In addition, for common people who lived in Edo, the Takanawa coast was utilized as a place for moon or birds viewing, boating, eating and drinking as well as gathering. Even Westerners visited the Takanawa coast and admired the coastal scenery. Many woodblock prints depicted foreigners riding along the Takanawa coast.

Unlike European people, Japanese people of the pre-modern age had a negative image neither on the sea nor the shore. This study clarifies that Japanese people in the pre-modern age regarded the sea and the shoreline as an object of the aesthetic appreciation.

(3) Unrooted European seaside culture

European seaside culture was introduced to Japan through Western people who engaged in commerce and trade with Japan in the early stage of modernization in Japan. Seaside bunds and pleasure piers were typical of this kind.

The introduced Western seaside culture, however, did not root deeply into the Japanese soil. One of their reasons can be pointed out as follows; Japanese people had already experienced the beauty of the Takanawa coast. Hence, there is a possibility that a feeling of seaside openness that a bund or a pleasure pier emphasized was not sufficiently attractive for the Japanese people.

\section{CONCLUSIONS}

In general, the Japanese people in the pre-modern age regarded the sea as a holy world. Particularly in the southern part of the Japanese archipelago people believed that the holy place existed at the bottom of the sea of the far-off east. In particular in fishery villages people believed that beach was the place where gods landed and met with the villagers.

It can be also pointed out that Japanese people in the pre-modern age united the sea and the beach in a single entity. On the contrary, people in Europe conceived of the sea as an uncivilised world where monsters lived. European people also regarded the seashore as a border between our world and the underworld where no order/discipline existed.

Seaside open space already existed in the Tokugawa era (1603-1868) before the Western people came to Japan for commerce. For example, Takanawa coast was loved and highly popular among travellers and citizens, and was utilized as a place for moon or birds viewing, boating, eating and drinking as well as gathering. The introduced Western seaside culture such as seaside bunds and pleasure piers did not root deeply into the Japanese soil. 
These results demonstrate that the influence of the European seaside culture on the Japanese society in the early modernization stage was limited as far as an aesthetic sense toward the shore was concerned. This study indicates that the Japanese people have their own visual sense with unique historical background, and will pursue ways for the sustainability of their way of life based on their own.

\section{REFERENCES}

[1] Urita, S., Representation of mountains in picturesque aesthetics (in Japanese), Bulletin paper, Kobe University (3), pp. 93-105, 2006.

[2] Corbin, A., The Lure of the Sea, Penguin, 1994.

[3] Christopher, M., The English at the Seaside, Collins, 1947.

[4] Fukazawa, K., Seaports and Civilization (in Japanese), Yamakawa co., 2002.

[5] Kato, H., Comparative analysis between Japan and West on Gaze to Port (in Japanese), Master Thesis, Hokkaido University, 2015.

[6] Fischer, R. \& Walton, J. British Piers, Thames and Hudson, 1987.

[7] Yanagida, K., Sea Ways (in Japanese), Chikuma sosho 85, Chikuma Publishing Co., 1967.

[8] Chii, A. Why Do Fishermen Live Facing to the Sea? (in Japanese), Kosakusha Publishing Co., 2012.

[9] Kamimukaenomichi, available at http://kamimukaenomichi.com/, (accessed December 3, 2015).

[10] Paris National Library, Life Under the Sea, available at http://expositions.bnf.fr/lamer/ expo_us/salle1/index.htm, (accessed December 3, 2015).

[11] Sakai, A., The hybridization of ideas on public parks: introduction of Western thought and practice into nineteenth-century Japan. Planning Perspectives, 26(3), International planning history society, 2011.

[12] Hashizume, S., Kaiyutoshi-Modernization of Urban Resort (in Japanese), Hakuchisha Publishing co., 1992. 